\title{
Application of FPA in British Literature Teaching
}

\author{
Shaojun Duan* \\ School of Foreign Languages \\ Kunming University \\ Kunming, China \\ duanshaojun2709@126.com
}

\begin{abstract}
FPA is the abbreviation of Focus Personality Analysis. In FPA, four colors, i. e. red, blue, yellow, and green respectively represent liveliness, perfection, enterprise, and peace. This paper tries to interpret novels in a new perspective in British literature teaching, i. e. employing the FPA to interpret three couple's personalities in "Pride and Pre judice" in order to help students to understand that personality or character has color, different characteristics have different influences on people's views of marriage and their choice as shown in the novel. As a result, under the teacher's guidance, students can comprehend this novel from a new angle and in a more profound level.
\end{abstract}

Keywords_FPA; British Literature Teaching; Pride and Prejudice; Characters' personality

\section{INTRODUCTION}

Jane Austin's six novels all describe more than marriage[1]64. Among which "Pride and Prejudice" is the most popular one to readers nowadays due to the different versions of movie adaptation. Accordingly, scholars are also attracted by it and contributed lots of research papers in the English literature study. In Chinese academic field, many scholars have researched "Pride and Prejudice" from various perspectives, and the angle of analyzing the main characters' personalities has also been touched. Yet, the angle of analyzing the main characters' personalities by using FPA is void at present.
In British Literature Teaching class, her masterpiece "Pride and Prejudice" is an inevitable teaching material. In the novel we see the intelligent and attractive Elizabeth, beautiful and pure Jane, gentle and handsome Bingley, proud and righteous Darcy, vulgar and snobbish Collins, small- minded and arrogant Lady Catherine [2]. Since the novel is classic, it's hard for the teachers to teach college or university students in a new perspective. Considering this situation, I, as a university English teacher in British and American Literature, try to find a new way to teach this novel in my class, i. e. employing FPA (Four-color Personality Analysis ) from Le Jia to interpret three couple's personalities in "Pride and Prejudice" in British Literature Teaching in order to help students to understand that personality or character has color, different characteristics have different influences on people's views of marriage and their choice as shown in the novel.

\section{A BRIEF REVIEW OF FPA}

Before teaching students to use FPA to analyze the novel, it's necessary for teachers to introduce FPA to students in the first place.

Below is my summary of four colors' characteristics, based on Le Jia's FPA theory:

TABLE I. FOUR COLORS’ CHARACTERIST ICS, BASED ON LE JIA’S FPA THEORY

\begin{tabular}{|c|c|c|c|c|}
\hline & Red & Blue & Yellow & Green \\
\hline advantages & $\begin{array}{l}\text { (1) Having a positive } \\
\text { attitude } \\
\text { (2) Sincere active } \\
\text { (3) Expressive } \\
\text { (4)Full of enthusiasm }\end{array}$ & $\begin{array}{l}\text { (1)Thinking meticulous } \\
\text { (2) Caring for others secretly } \\
\text { (3) Sensitive and tender } \\
\text { (4) Being good at planning }\end{array}$ & $\begin{array}{l}\text { (1) Quick action } \\
\text { (2) Goal oriented } \\
\text { (3) Notliable to } \\
\text { (4) Perseverant }\end{array}$ & $\begin{array}{l}\text { (1) M ild and peace } \\
\text { (2) Consider ing for others } \\
\text { (3) Being in harmony with the rest of } \\
\text { the world } \\
\text { (4) Good at coordination }\end{array}$ \\
\hline disadvantages & $\begin{array}{l}\text { (1)Being prone to } \\
\text { emotional outbursts } \\
\text { (2) M aking jokes in } \\
\text { wrong occasions } \\
\text { (3)Breaking promises }\end{array}$ & $\begin{array}{l}\text { (1)Affective fragility } \\
\text { (2)Being fond of criticism } \\
\text { and picky } \\
\text { (3) Communicati on with } \\
\text { people passively } \\
\text { (4)Tending to get in security }\end{array}$ & $\begin{array}{l}\text { (1) Unrepentant admission } \\
\text { (2)over -controlling } \\
\text { (3) A ggressive } \\
\text { (4)Easy to get angry }\end{array}$ & $\begin{array}{l}\text { (1) Refusing to change } \\
\text { (2) Timid and passive } \\
\text { (3) Nothaving own ideas } \\
\text { (4) Lack of originality }\end{array}$ \\
\hline
\end{tabular}

FPA is the abbreviation of Focus Personality Analysis. The source of FPA is Hippocrates's theory: four humors. They were black bile (gr. melan chole), yellow bile (gr. chole), phlegm (gr. phlegma), and blood (lat. sanguis). A humor was also referred to as a cambium (pl. cambia or cambiums)[3]147. A different personality type matches to each of the four types of humors. If a person is always involved in deep thoughts, we may say he or she has a melancholic disposition. If someone has lots of and big ambition, energy, passion, and try to impose on others, we may say he or she is yellow bile. Phlegmatics tend to be selfcontent and kind. People of a sanguine temperament tend to enjoy social gatherings, making new friends and tend to be quite loud. They are usually quite creative and often daydream. 
In China, Chinese psychological expert, Le Jia, based on the basis of the above theories, develops the theory of FPA (Four-color Personality Analysis). FPA system will divide people's character into: red, blue, yellow and green. Human character is complex, so a person could not simply control by a kind of color. Putting four kinds of color together to comprehend is the most complete description of one person's character. But, usually one or two kinds of color occupy a leading position in one person. It can help us solve the problems of life, marriage, family and other interpersonal relationships[4]1.

In FPA, red, blue, yellow, green four colors are respectively a characteristic trait. Red represents liveliness, blue for perfection, yellow represents enterprise, while green represents peace $[4] 3$.

\section{InTERPRETING Characters' PeRsonalities IN "PRIDE AND PREJUdice" BY EMPLOYING FPA}

In the following parts, it's time for teachers to use FPA to analyze three couples in "Pride and Prejudice" in order to help students to understand that personality or character has color, different characteristics have different influences on people's views of marriage and their choice as shown in the novel. As a result, students can comprehend this novel in a profound and new angle.

\section{A. Elizabeth Bennet and Fitzwilliam Darcy}

Elizabeth is Red. Le Jia said Red people like to pursue romantic love. They believe that marriage should build on love. So we can understand why she refuses Collins and Darcy at the first sight. Elizabeth is not as beautiful in appearance as her older sister Jane, but she is still quite attractive compared to other sisters in this family. The most important of all, are her humor, intelligence, sincerity, pride, prejudice, and emotion which helps her to win Darcy's hands at last. As for humor and intelligence, we may say she owns intelligence and his father's sense of humor and irony, but without his cynicism, which can be proved by her attitudes toward her funny mother and her bosom friend's marriage. As for sincerity, many things prove this, for example, when her sister Jane became ill in Bingley's home, Elizabeth without considering the decorum, tramped off a long way in big rainy days through the mud to visit and nurse her sister which shows her sincere love for her sister. As for pride and emotion, we can see these personal features bring her much trouble beside the good result. Trouble one is pride and prejudice from Darcy; Trouble two is Darcy's aunt's coming to her house to ask her to promise not to marry with Darcy because of her refusal to Darcy's proposal. Trouble three is her quarrel with Darcy and her liaison with Wickham, an irresponsible soldier in a regime and a liar to Darcy because she only listened to one side word, which shows her emotion of passion for doing something. All the above mentioned and discussed merits and deficiencies about Elizabeth make her a round character in this novel, which explains clearly the reason why Darcy becomes more and more attractive to her and makes his final decision to marry with her.

Different from Elizabeth, Darcy is Blue. According to Le Jia's theory, Blue people pursue perfect love. There are two examples to show this opinion. First, at the ball in the nearby town of Meryton, Bingley suggests Darcy to dance with Elizabeth, but Darcy refuses and makes comments, "She is tolerable, but not handsome enough to tempt me. "[5]133 He proceeds to declare he has no interest in women who are "slighted by other men." Second, one night when Elizabeth visits Jane at Bingley's home, the Bingley sisters, Darcy, and Bingley have a discussion on "accomplished women". After Darcy and Bingley list the attributes that such a woman would possess, Elizabeth declares that she has never seen that so many things such as capacity, taste, application, and elegance etc., as Darcy describes, can be united in one female's body, which implies that Darcy is far too demanding.

What is more, Blue people are not good at sweet talk, they like taking action to express their love. There are also several examples. One, Darcy calls on Lady Catherine and encounters Elizabeth whose presence leads him to a number of visits to Collins's home, where she is staying. Two, humbled by Elizabeth's rejection of his marriage proposal, Darcy has altered his conduct toward her and becomes a better gentleman. Three, while Elizabeth and the Gardiners continue to explore the grounds; Darcy himself suddenly appears and joins them in their walk, proving remarkably polite. This courteous behavior both illustrates his love for her and compels the growth of her estimation of him. Four, because of his love for Elizabeth, Darcy found Lydia and Wickman, and paid Wickman the money that facilitated the marriage, which rescues the entire Bennet family from disgrace. Last but not the least, Darcy goes against the wishes of his aunt, Lady Catherine de Bourgh by continuing to woo Elizabeth.

At last, both of them overcome all obstacles or hindrance to live happily together, including their respective pride and prejudice. So, we can make a conclusion that their marriage is based on affectionate and compassionate love with mutual understanding.

\section{B. Jane Bennet and Charles Bingley}

"Birds of a feather flock together, people of a mind fill into the same group. ”Jane and Bingley are Green. They two are so similar in nature and behavior that they we tend to put them together to discuss. Green people are mild and like peace so that their love is simple. That's why when they get married just because they love each other, not because Bingley is rich and Jane admires the prosperity and wants to marry into the rich family in order to own more money and higher status.

First, let's talk about Jane. Jane was the eldest child among the five sisters in the family. She was kind and mild to all the people around her so that we never observe in the novel she felt anger to anyone, even when she was mocked by Bingley's sister bitterly. She was also considerate to others, which may be proved by her good opinion of Darcy and found excuse for Bingley's sudden left and showing no sign of trying to get in touch with her by letter or through any other ways because as readers we know truly it's Darcy who persuaded his friend Bingley to leave Jane without saying goodbye when they two were feeling in love with each other passionately due to the family members' vulgar behavior in party in front of Darcy. Normally these personal characters of Jane will be regarded as 
the merits. Yet when we see them in another angle, we can also notice the deficiencies resulted from them. For example, being made use of by evil person and looked down upon by others, such as we mentioned earlier, Bingley's sister's bully of Jane in verbal language by attacking her family members' vulgar behavior and saying Jane was no exception among them. Besides these, we can also see Jane's stubbornness of refusing changing her own idea when Elizabeth tried to persuade her to react actively to Bingley's sudden left. Instead, she chose passive reaction that is, finding excuse for him and preferring to bear the bitterness in her deep heart.

Now it's time to talk about Charles Bingley in turn after Jane's discussion. Bingley was a handsome young man and received good family education and breeding. So he was always appearing cordial, mild and simple. It seemed that he never appeared discontented or dissatisfied with anything or anybody. The most important of all about him was his richness. At the beginning of this novel, the author comments it is a truth universally acknowledged that a single man possessing a large number of money must be in urgent need of a wife. Because of the truth, Bingley became the most obvious target and best choice of many mothers when they considered finding a husband for their daughters. That's why when MRs. Bennet heard Bingley was going to come to the town to spend the vocation, the mother was so happy and urged her husband to visit Bingley in order to possess the first chance to get acquaintance with Bingley. From this situation, readers can see during the later talking and touching between Bingley and MRs. Bennet, Bingley showed his passiveness and total acceptance towards MRs. Bennet's hospitality and her imposing ideas on him with ignoring her bad behavior, which also proves his consideration for others and his not having his own opinions as well. As for his not having ideas, the good example is his sudden leaving Jane without saying goodbye under his friend Darcy's persuasion as we have already mentioned in Jane's part. This also reveals Bingley's timid and passive attitude towards his loving affairs with many women, esp. with Jane. Therefore, we can say without Darcy's later change and help, Bingley and Jane could never come together and become a happy couple.

\section{Charlotte Lucas and Mr. Collins}

Lucas and Collins are Yellow. They two are goal-oriented people. They do not pursue romantic love, they tend to be realistic. So when Mr. Collins makes a proposal to her, she accepts right now. After accepting Mr. Collins’ proposal, she tells the reason to Elizabeth: You must be surprised, very much surprised-as lately as Mr. Collins was wishing to marry you. Yet when you stand in my shoe and think it over again, I think you will feel content with my choice. As you know unlike you I am a realistic person, so what I pursue is just only a comfortable and steady home. Based on this goal, Mr. Collins' condition can meet my needs considering his status and economic situation. From these words spoken by Charlotte Lucas, we can see that Charlotte is a pragmatic and realistic woman which makes a sharp contrast to Elizabeth. Being six years older than Elizabeth, in her eyes Charlotte does not think love is the most important and inevitable element in a marriage. Instead, a comfortable home based on economical foundation is her first and most concerning point. That is why when $\mathrm{Mr}$.
Collins makes the immediate proposal to her after being refused by Elizabeth; she accepts the proposal at once, which shows her goal clearly.

Mr. Collins is "a snobbish and material clergyman with ill manners." [6]211 He is going to get Mr. Bennet's property because the family has not male heirs who can inherit the property. Although Mr. Collins's social status is low, he wants to try hard to let people respect him by telling them that Darcy's aunt is his patroness. The real truth is like this: when the post of clergyman in Hunsford was not occupied by anyone by chance Darcy's aunt, Lady Catherine, recommended him to take the post. As for anyone this kind of thing was not worth boasting, yet to Mr. Collins, it's a good chance to sell him by making good use of and amplify the connection between him and the old rich lady. From this behavior, we can see Mr. Collins is a goal-oriented person like Charlotte; the difference is that he is a liar to some extent and has selfish intention, while she is just a realist and frank to her friend. The reason behind this is probably about a face question, that is, Mr. Collins pays more attention to his own face so that he dares to venture amplifying the relationship between him and the old rich lady in order to gain people's respect. It seems to us he is a vanity. He regards his face very heavy. He can marry without love. He adopts Lady Catherine's suggestion and tries to find a woman to marry with, just wanting a wife to look after his house. So, we can see their marriage is based on economics and mutual comfort.

\section{CONCLUSION}

"Pride and prejudice" is Austin's great work. Through the discussion of the different marriages and love, Austin shows readers her ideas or attitudes about the relationship between love and marriage, between marriage and property, or social status, thus offers her ideal marriage. Nowadays, we see many people resemble the couple of Charlotte Lucas and Mr. Collins; they mainly marry for material things, for comfort not for love. In my eyes, this kind of view on marriage is not so acceptable. I am agreed with Austin's view of love and marriage. I think a successful marriage should be based on love and a person's inner quality. Today, her book still can be the guide telling us the view of marriage at her time and in modern time.

Through those above profound analysis and interpretation to college or university students in British literature teaching, I believe the characters in "Pride and Prejudice" are vividly standing before them now, and all of them must have left students a deep impression: intelligent and attractive Elizabeth, beautiful and pure Jane, gentle and handsome Bingley, proud and righteous Darcy, vulgar and snobbish Collins, smallminded and arrogant Lady Catherine. FPA tells us character has color, and different characteristics have different influences on their views of marriage and their choice. Thus, we can use this tool to solve the relationship of our character and marriage. It is very helpful for us to analyze one's character and make sure which one is the one we should marry with correctly. We know if many similarities exist in people's personal characters, people could understand each other without much difficulty, like the couple of Jane and Bingley. With different characters, people will attract each other for different advantages, like the couple of Elizabeth and Darcy. 
As a result, under the teacher's guidance, students can comprehend this novel from a new angle and in a more profound level. Furthermore, hopefully young college learners can learn some lessons from interpreting this novel, which may be helpful in their near future choice in love and marriage.

\section{REFERENCES}

[1] W. Shouren, Selected Readings in British Literature. Beijing: Higher Education Publishing House, 2005.

[2] L. Qin, "Main Characters Analysis of Pride and Prejudice, "in College Forum, vol. XXVII, W. Jianyi, Eds. Jinan: Science \& Technology Information, 2008, pp. 197-218. (In Chinese)

[3] R. Burton, The Anatomy of Melancholy. NY: The New York Review of Books, 2001.

[4] L. Jia, Identify People through Color: Interpretation of FPA Character Color Code. Shanghai: Wenhui Publishing House, 2006. (In Chinese)

[5] J. Austen, Pride and Prejudice. Shanghai: World Books Press, 2008.

[6] L. Yiqing, L. Jiong, A Brief History of English Literature. Beijing: Foreign Language Teaching and Research Press, 2008. 